\title{
Changes in lymphocyte single strand breakage and liver function of workers exposed to vinyl chloride monomer
}

\author{
Chung-Li Du*a, Min-Liang Kuo ${ }^{b}$, Hsiao-Ling Chang ${ }^{a}$, Tzong-Jen Sheu ${ }^{b}$, \\ Jung-Der Wang ${ }^{\mathrm{a}}$ \\ ${ }^{a}$ Institute of Occupational Medicine and Industrial Hygiene, College of Public Health, National Taiwan University. No. 1, Sec. 1, \\ Jen-Ai Rd., Taipei, Taiwan \\ ' Institute of Toxicology, College of Medicine, National Taiwan University. No. 1, Sec. 1, Jen-Ai Rd., Taipei, Taiwan
}

Accepted 13 January 1995

\begin{abstract}
Vinyl chloride monomer (VCM) is a suspected human carcinogen. Its metabolite, chloroethylene epoxide, is able to alkylate the DNA molecule and to produce single strand breakage (SSB). A total of 244 workers from 4 polyvinyl chloride (PVC) manufacturing factories were recruited to assess the SSB of their peripheral lymphocyte DNA. The method of alkaline unwinding and hydroxyapatite chromatography was used to detect and calculate frequencies of SSB. In addition, hepatitis B and C markers and the liver function of the workers were also examined. The worker's cumulative exposures to VCM were retrospectively constructed from the current monitoring data and each worker's job history. Multiple linear regression models were constructed to predict the worker's level of SSB and liver functions based on various exposure indices and variables, such as age, sex, smoking, drinking, and hepatitis markers. The results showed that current smoking and drinking status, and the presence of VCM exposures on the previous day were 3 major determinants of the level of SSB. Among the liver function tests, only $\gamma$-glutamyl transpeptidase (GGT) was associated with current VCM exposures. In contrast, aspartate aminotransferase (AST), alkaline phosphatase (ALP) and alanine aminotransferase (ALT) were mainly affected by the presence of hepatitis B surface antigen (HBsAg) or anti-hepatitis $\mathrm{C}$ virus (anti-HCV). We conclude that GGT should be considered to be included in the regular health screening of VCM workers, and that the SSB method may not be suitable for long-term monitoring of cumulative exposure because of the quick DNA repair mechanism in humans.
\end{abstract}

Keywords: Single strand breakage (SSB); Peripheral lymphocyte; Alkaline unwinding and hydroxyapatite chromatography; Gamma glutamyl transpeptidase (GGT); Time-weighted average (TWA)

\section{Introduction}

Vinyl chloride monomer (VCM), mainly as a raw material for the manufacturing of polyvinyl chloride (PVC) resins, was considered to have low

* Corresponding author. toxicity until 1949 when workers with hepatitis were noticed. Hepatomegaly, splenomegaly, Raynaud's phenomenon, scleroderma and acroosteolysis were subsequently reported to be associated with VCM exposure [1-6]. VCM was suspected to be a potential carcinogen since the 1970 s due to several animal and epidemiological 
studies. Since then, agreement on the development of liver angiosarcoma in VCM-exposed workers was gradually achieved, and increased odds ratios in brain and lung cancer were usually mentioned [7-9]. The mechanism of the VCM carcinogenic effect is usually thought to be through an epoxide generation, which causes DNA alkylation [10]. However, a normal human body has many repair mechanisms to DNA damage, such as dealkylation. DNA adduct may be excised and no carcinogenic effect will show up. Under the condition of heavy burden from excessive VCM exposure, repair defect ensues and lesions may be expressed. These ranged from DNA-base-pair adduct, substitution, addition, deletion, DNA strand separation or sister chromatid exchange (SCE) to chromosomal or gene abnormality [11]. Cytogenetic study such as SCE and chromosomal aberration (CA) that reflect chronic exposure were tested on these workers [12], and many of them showed positive results. However, these tests were time consuming, and since Mäki-Paakkanen et al. [13], reported a simultaneous elevation of frequencies of $\mathrm{CA}$ and single strand breakage (SSB) among styrene workers we suspect that SSB might be an earlier genotoxic biomarker than CA or SCE. Thus, we performed a DNA breakage test to study the early genotoxicity upon VCM exposure. Routine liver function tests were also done to search for any early indicator of liver damage.

\section{Materials and methods}

Four PVC manufacturing factories with 244 workers in Taiwan were studied. We first performed personal and area samplings to measure the VCM concentration [14]. This was followed by physical examination 3 months later. A comprehensive physical examination which included a questionnaire about personal and working history was performed in the morning of a workday. Blood was drawn for tests of hemoglobin, white blood cell, serum protein, and alanine aminotransferase (ALT), aspartate aminotransferase (AST), alkaline phosphatase (ALP), $\gamma$-glutamyl transferase (GGT) as well as creatinine, hepatitis $B$ antigen (HBsAg), anti-hepatitis $\mathrm{C}$ virus (anti-HCV), and DNA breakage test of peripheral lymphocyte.
HBsAg and anti-HCV were examined by radioimmunoassay (RIA, Abbott Laboratory, IL) and enzyme-immunoassay (EIA, Abbott Laboratory, Wiesbaden, Germany), respectively. To determine SSB, the method was used as described by Erixon and Ahnstrom [15]. Briefly, lymphocytes were isolated from Ficoll-Hypaque and lysed in $0.03 \mathrm{M}$ $\mathrm{NaOH}$, then kept in dark for $5 \mathrm{~min}$, until the cell membrane ruptured. The solution was then neutralized to $\mathrm{pH} 6.8$ with $20 \mathrm{mM} \mathrm{NaH} \mathrm{PO}_{4}$. After a short sonication, sodium dodecyl sulfate (final concentration 0.25 ) was added. The DNA samples were then put on the hydroxylapatite columns at $60^{\circ} \mathrm{C}$. The single and double strand DNA was eluted with $0.08 \mathrm{M}$ and $0.25 \mathrm{M}$ potassium phosphate buffer, respectively. DAPI (4,6diamidino-phenylindole $2 \mathrm{HCl}$ ) was added and the amount of DNA was measured by fluorometry. The fraction of double strand DNA (FDs) was calculated, and logFDs was taken as representative of level of SSB [15,16]. The personal exposure to VCM was measured and medium time-weighted average (TWA) was assigned to each job. Because every job was performed with at

Table 1

Median exposure concentrations of different categories of exposure and jobs in PVC factories

\begin{tabular}{|c|c|c|}
\hline $\begin{array}{l}\text { Catergory } \\
\text { of exposure }\end{array}$ & Job description & $\begin{array}{l}\text { Medium TWA } \\
\text { concentration } \\
\text { (ppm) }\end{array}$ \\
\hline \multirow[t]{4}{*}{ High } & Unloading PVC & 73.8 \\
\hline & Adding catalyst & 63.7 \\
\hline & Cleaning tank (water jet) ${ }^{a}$ & 38.2 \\
\hline & Cleaning tank (manual) & 21.9 \\
\hline \multirow[t]{7}{*}{ Medium } & Unloading VCM & 4.85 \\
\hline & Foreman & 1.76 \\
\hline & Control room & 1.73 \\
\hline & Supervisor & 1.34 \\
\hline & Engineering control & 1.34 \\
\hline & Stripping tank & 1.34 \\
\hline & Secretary & 1.3 \\
\hline \multirow[t]{6}{*}{ Low } & Drying operation & 0.99 \\
\hline & Laboratory testing & 0.88 \\
\hline & Hygienist & 0.68 \\
\hline & Machinist & 0.67 \\
\hline & PVC storage & 0.43 \\
\hline & Gatehouse & 0.36 \\
\hline
\end{tabular}

aShort-term exposure. 
Table 2

Demographic and physical data of workers in 3 exposure categories

\begin{tabular}{lccc}
\hline & \multicolumn{2}{l}{ Exposure categories } & \\
\cline { 2 - 4 } & High & Medium & Low \\
\hline No. of workers & 16 & 104 & 122 \\
Current mean exposure (ppm) & $56.3(22.6)^{*}$ & $1.8(1.0)$ & $0.67(0.26)$ \\
Age (years) & $39.8(9.3)$ & $40.2(9.2)$ & $39.5(9.5)$ \\
Height (cm) & $167.0(2.6)$ & $167.2(6.0)$ & $168.2(5.8)$ \\
Body weight (kg) & $68.0(9.2)$ & $65.6(9.0)$ & $66.3(9.4)$ \\
BMI & $24.4(3.3)$ & $23.4(2.7)$ & $23.4(2.8)$ \\
Systolic pressure (mmHg)** & $121.3(13.6)$ & $115.2(13.9)$ & $116.0(12.1)$ \\
Diastolic pressure (mmHg) & $83.0(9.6)$ & $76.7(9.3)$ & $76.9(9.5)$ \\
Smoking (pack/year) & $106.3(204.3)$ & $85.8(144.4)$ & $82.8(147.2)$ \\
Alcohol drinking (g/week) & $40.0(110.0)$ & $42.6(294.6)$ & $34.1(142.4)$ \\
Duration of work (months) & $158(105)$ & $177(114)$ & $170(117)$ \\
\hline
\end{tabular}

* Mean (standard deviation).

$* * P<0.05$ (general linear model test).

least 4 personal measurements, we have successfully constructed 15 different exposure groups each with a medium TWA value (Table 1).

The worker's current exposure was calculated according to his present time activity data. The cumulative exposure was the summation of each job exposure concentration (in ppm 8-h TWA) times the duration (in months) of that job. Log transformation also was tried for both current and cumulative exposure indices during our multivariate regression analysis to seek a better fit. These data were analyzed with the SAS program [17], using general linear and multiple regression models.

\section{Results}

There are totally 244 workers examined, including 7 females. One of the subjects showed clinically overt hepatitis B signs and symptoms and he was excluded from our study. The average

Table 3

Laboratory results of 3 exposure groups

\begin{tabular}{|c|c|c|c|}
\hline & \multicolumn{3}{|l|}{ Exposure groups } \\
\hline & High & Medium & Low \\
\hline Hemoglobin $(\mathrm{g} / \mathrm{d})$ & $16.1(1.0)^{*}$ & $15.8(1.1)$ & $15.9(1.2)$ \\
\hline White blood cell $(\times 1000 / \mu)$ & $6.5(1.6)$ & $6.5(1.4)$ & $6.5(1.4)$ \\
\hline Creatinine (mg/dl) & $7.6(0.4)$ & $7.6(0.4)$ & $7.6(0.4)$ \\
\hline Total protein $(\mathrm{g} / \mathrm{dl})$ & $4.6(0.2)$ & $4.5(0.2)$ & $4.5(0.3)$ \\
\hline Albumin (g/dl) & $3.0(0.3)$ & $3.1(0.4)$ & $3.1(0.3)$ \\
\hline Globulin (g/dl) & $1.2(0.2)$ & $1.2(0.1)$ & $1.2(0.1)$ \\
\hline AST (IU/A) & $26.2(12.3)$ & $23.3(11.0)$ & $21.8(8.7)$ \\
\hline ALT (IU//) & $29.5(21.0)$ & $23.1(20.2)$ & $20.8(14.3)$ \\
\hline GGT (IU//)** & $61.9(92.1)$ & $28.6(18.2)$ & $31.1(26.2)$ \\
\hline ALP (IU/) & $172.3(33.6)$ & $166.0(42.3)$ & $168.8(42.0)$ \\
\hline$\%$ with hepatitis B surface antigen & 18.8 & 22.1 & 17.2 \\
\hline$\%$ with anti-hepatitis $\mathrm{C}$ virus & 0 & 2.9 & 3.3 \\
\hline Level of single strand DNA breakage & $0.124(0.087)$ & $0.125(0.095)$ & $0.126(0.099)$ \\
\hline
\end{tabular}

* Mean (standard deviation).

$* * P<0.01$ (general linear model test). 
Table 4

Multivariate regression models of serum enzyme activities: the listed figures are regression coefficients (S.E.) of different independent variables

\begin{tabular}{lllllllr}
\hline $\begin{array}{l}\text { Serum } \\
\text { enzyme }\end{array}$ & Intercept & BMI & $\begin{array}{l}\text { Current VCM } \\
\text { exposure }\end{array}$ & $\begin{array}{l}\text { Alcohol } \\
\text { drinking }\end{array}$ & HBsAg & Anti-HCV & Model $R^{2}$ \\
\hline AST & N.S. & $1.2(0.43)$ & N.S. & N.S. & $8.1(3.1)$ & $27.4(7.5)$ & 0.12 \\
ALT & -48.3 & $2.9(0.82)$ & N.S. & N.S. & $13.4(5.8)$ & $36.0(14.1)$ & 0.11 \\
GGT & -57.3 & $3.7(0.73)$ & $0.57(0.14)$ & N.S. & N.S. & N.S. & 0.19 \\
ALP & 136 & N.S. & N.S. & N.S. & $14.6(7.1)$ & N.S. & 0.03 \\
\hline
\end{tabular}

${ }^{a}$ Current exposure: measured TWA (in ppm) value 3 months prior to blood tests.

N.S. indicates non-significant for $P<0.05$.

age is 40 years old, and the mean duration of employment is 14 years. We also classified these workers into 3 groups according to their current TWA exposure concentration $(>10 \mathrm{ppm},<1$ ppm, and in between). The basic demographic data is summarized in Table 2 . It revealed no significant difference in these 3 groups. The comparison of biochemical testing results is shown in Table 3, which indicated that only GGT is significantly higher in the high exposure group, while the level of SSB was rather close among these 3 groups. A multiple regression analysis was performed with liver enzymes as the dependent variable and drinking status, $\mathrm{HBs} \mathrm{Ag}$, anti-HCV and various exposure indices as the independent variables. We found that ALT and AST were determined by anti-HCV, HBsAg, and body mass index (BMI), while VCM exposure and drinking

Table 5

Regression models of level of single strand breakage using different exposure indices and other predicting variables

\begin{tabular}{|c|c|c|c|c|c|c|}
\hline Meaning of exposure index & Exposure index & Intercept & $\begin{array}{l}\text { Age } \\
\text { (years) }\end{array}$ & $\begin{array}{l}\text { Current smoking } \\
\text { (cig./day) }\end{array}$ & $\begin{array}{l}\text { Current drinking } \\
\text { (g/week) }\end{array}$ & $\begin{array}{l}\text { Model } \\
R^{2}\end{array}$ \\
\hline $\begin{array}{l}\text { Current exposure } \\
\text { concentration (in ppm) }\end{array}$ & N.S. & $0.14(0.03)^{a}$ & N.S. & $0.0018(0.0008)$ & $0.00007(0.00003)$ & 0.06 \\
\hline $\begin{array}{l}\text { Log transformation of current } \\
\text { exposure concentration } \\
\text { (log(ppm)) }\end{array}$ & N.S. & $0.14(0.03)$ & N.S. & $0.002(0.0008)$ & $0.00007(0.00003)$ & 0.07 \\
\hline $\begin{array}{l}\text { Cumulative exposure } \\
\text { (ppm/month) }\end{array}$ & N.S. & $0.13(0.03)$ & N.S. & $0.0016(0.0008)$ & N.S. & 0.07 \\
\hline $\begin{array}{l}\mathrm{X} 1=1, \mathrm{X} 2=0 \text { mean exposure } \\
\text { concentration of the day } \\
\text { before SSB test }>1 \mathrm{ppm}\end{array}$ & $X 1=0.05(0.03)$ & $0.08(0.04)$ & N.S. & $0.0018(0.0008)$ & $0.00007(0.00003)$ & 0.08 \\
\hline $\begin{array}{l}X 2=1, X 1=0 \text { mean exposure } \\
\text { concentration of the day } \\
\text { before } S S B \text { test }<1 \mathrm{ppm} \\
X 1=0 \text { and } X 2=0, \text { no } \\
\text { exposure the day before } \\
\text { SSB test }\end{array}$ & $X 2=0.06(0.03)$ & & & & & \\
\hline $\begin{array}{l}X=1 \text {, working on the day } \\
\text { before } S S B \text { test } \\
X=0 \text {, absent from work the } \\
\text { day before SSB test }\end{array}$ & $0.05(0.03)$ & $0.08(0.04)$ & N.S. & $0.0018(0.0008)$ & $0.00007(0.00003)$ & 0.08 \\
\hline
\end{tabular}

The listed figures are regression coefficients (S.E.M.); all are significant with $P<0.05$.

N.S, nonsignificant. 
had no influence, as shown in Table 4. GGT activity was influenced by current exposure levels and BMI. Although alcohol drinking has been known to be a major determinant, it only reached borderline significance $(P=0.09)$ in our multivariate analysis (not shown in Table). The regression model of the level of SSB showed that current smoking and drinking status had significant effect, but cumulative amounts of smoking and drinking did not. The current and cumulative exposure of VCM had no effect on the level of SSB. However, there is a significant difference between those who were absent from work the day before blood was drawn and those who still worked that day after control of confounding by other factors (Table 5). When we take the 31 persons who were examined for both personal sampling of VCM and DNA breakage test, we found that the correlation between the level of SSB and the concentration of current TWA value is relatively small $\left(r^{2}=0.014\right)$.

\section{Discussion}

Methods of detecting DNA damage repair include detection of damaged bases, detection of strand breaks, and detection of incorporation of new bases [18]. DNA unwinding is thought to be a very specific method to detect single strand breaks [19]. Single strand DNA exists in normal blood lymphocyte and repairs continually. In one study, it was shown that after $24 \mathrm{~h}$ of exposure of mice to VCM, the level of SSB is correlated with VCM concentration, and after $20 \mathrm{~h}$ post-exposure, $80 \%$ of DNA damage had been repaired [20]. Another study showed that after single exposure to methylmethane sulphonate, the level of the SSB first increased, then decreased gradually. At the sixth day, the level of SSB is similar to that of the control group [21].

In our study, we have not found any significant increase of SSB associated with cumulative or current VCM exposure, but instead, we found that after stopping exposure for just 1 day, the level of SSB is significantly less than in those in which exposure was not stopped after controlling other possible confounding factors such as smoking and drinking. This may suggest that the repair of DNA damage in humans is very fast. Although animal experiments showed a linear relationship between the exposure dose and level of SSB, we cannot find a clear linear relationship between VCM exposure and DNA breakage. The reasons may be as follows. First, the exposure assigned is probably not accurate enough because the current exposure dose was estimated through a cross-sectional area sampling, and not through long-term constant personal samplings. Moreover, although there has been no major change in working processes, the exposure 3 months ago may not directly reflect the current exposure level. Second, other confounding factors may exist, such as the T/B lymphocyte ratio, because it was usually thought that only $\mathrm{T}$ lymphocytes had an ability to repair [22]. Third, the time of drawing blood is in the morning of the workday instead of at the end of shift, so the lymphocytes have had a rest time for at least nearly 10 $h$ which may be long enough for a major repair, and we were unable to document a clear doseresponse relationship. Therefore, we recommend future study of SSB should have the workers' personal air sampling performed on the same day and the blood drawn either at the end of the shift or compared before and after the shift to avoid the above problems.

The studies in the 1970s showed a higher prevalence of abnormal AST, ALT and ALP in VCMexposed workers [23-26]. However, Sugita et al. [27] reported that VCM probably had no effect on these enzymes after control of confounding by other risk factors. Through a multivariate regression analysis we have also found that AST, ALT were associated with hepatitis $B$ and $C$ alone, and had nothing to do with the VCM exposure.

GGT was thought to be associated with VCM exposure, especially under high exposure conditions $[28,29]$. We have also found that GGT elevation was correlated with high current exposure levels. Since it was also known that BMI, alcohol and diabetes might influence the level of GGT [30], the interpretation of GGT elevation should be carried out with caution. However, our multivariate analysis has already controlled these potential confounding factors and still showed a consistent elevation of GGT along with a higher level of current (but not cumulative) exposure. 
Besides, as workers in the high and medium exposure groups were comparable with the low exposure group in all demographical characteristics, and all subjects under study were not known to have any pancreas, heart, kidney or lung diseases, the association of the GGT elevation with a higher current exposure to VCM cannot be explained by any other alternative hypotheses. Although Sugita et al. [27] could not find such a correlation, they had no sampling data available. In this study, we have constructed a personal TWA value as well as cumulative exposure indices for each worker. Thus, our classification of exposure indices may be more accurate than in other previous studies, and is more likely to detect such an association. Therefore, we conclude that the elevation of GGT along with a high current exposure to VCM may be real.

The mechanism of GGT elevation among VCM workers has not been clear so far. It is recognized that GGT catalyzes the transfer of the $\gamma$-glutamyl group of peptides, such as glutathione, to other amino acids. In mice exposed to carcinogens, reduction of glutathione was usually accompanied by an elevated GGT [31], which was interpreted as a feed-back mechanism of DNA repair. Another study proposed that the elevation of GGT might be due to a selective advantage of the cell in response to the toxic environment created by the carcinogen [32]. Thus, it might be speculated that VCM-associated GGT elevation is probably an early indication of DNA repair or a cellular response to carcinogenic stress, and GGT might be useful in the long-term follow-up health screening of VCM workers.

In conclusion, we found that the DNA unwinding method may be a sensitive method to reflect short-term DNA damage and repair status, but it cannot be used as an indicator for long-term monitoring of cumulative exposure. We recommend methods reflecting a more persistent damage, such as SCE or CA be tested to compare the results in the future. Also, due to the association between current VCM exposure and GGT elevation, it is possible that some degree of genotoxicity may exist in early stage of carcinogenesis for VCM workers. We therefore recommend the GGT test be performed on the regular screening of liver function for these workers.

\section{Acknowledgement}

We are indebted to the National Science Council for the support of this study, NSC 81-0421-F-002-539-Z.

\section{References}

[1] Wilson, R.H., McCormick, W.E., Tatum, C.F. and Creech, J.L. (1967) Occupational acroosteolysis. A report of 31 cases. J. Am. Med. Assoc. 201, 577-581.

[2] Harris, D.K. and Adams, W.G.F. (1967) Acro-osteolysis occurring in men engaged in the polymerization of vinyl chloride. Br. Med. J. 5567, 712-714.

[3] Juhe, S., Lange, G.E., Stein, G. and Veltman, G. (1973) On the so called Vinyl Chloride disease. Dutsch. Med. Weschr. 98, 2034-2037.

[4] Dinman, B.D., Cook, W.A., Whitehouse, W.M., Magnuson, H.J. and Ditcheck, T. (1971) Occupational acroosteolysis. I. An epidemiological study. Arch. Environ. Health 22, 61-73.

[5] Cook, W.A., Giever, P.M., Dinman, B.D. and Magnuson, H.J. (1971) Occupational acroosteolysis. II. An industrial hygiene study. Arch. Environ. Health 22, 74-82.

[6] Dodson, V.N., Dinman, B.D., Whitehouse, W.M., Nasr, A.N.M. and Magnuson, H.J. (1971) Occupational acroosteolysis. III. A clinical study. Arch. Environ. Health 22, 83-91.

[7] Wong, O., Whorton, M.D., Foliart, D.E. and Ragland, D. (1991) An industry-wide epidemiologic study of vinyl chloride workers, 1942-1982. Am. J. Ind. Med. 20, 317-334.

[8] Wu, W., Steenland, K., Brown, D., Wells, V., Jones, J., Schulte, P. and Halperin, W. (1989) Cohort and casecontrol analyses of workers exposed to vinyl chloride: an update. J. Occup. Med. 31, 518-523.

[9] Heldaas, S.S., Langard, S.L. and Andersen, A. (1984) Incidence of cancer among vinyl chloride and polyvinyl chloride workers. Br. J. Ind. Med. 41, 25-30.

[10] Bolt, H.M., Filser, J.G. and Laib, R.J. (1982) Covalent binding of haloethylenes. In: R. Synder, D.V. Parke, J.J. Kocsis, D.J. Jellow, G.G. Gibson and C.M. Witmen (Eds.), Biological Effects, Plenum Press, New York, pp. 667-683.

[11] Brusick, D. (1987) Fundamentals of genetic toxicity. In: D. Brusick (Ed.), Principles of Genetic Toxicology, New York and London, Plenum Press, pp. 47-48.

[12] Sinues, B., Sanz, A. and Bernal, M.L. (1991) Sister chromatid exchanges, proliferating index, and micronuclei in biomonitoring of internal exposure to vinyl chloride monomer in plastic industry workers. Toxicol. Appl. Pharmacol. 108, 37-45.

[13] Māki-Paakanen, J., Walles, S., Osterman-Golkar, S. and Norppa, H. (1991) Single-strand breaks, chromosome aberrations, sister-chromatid exchanges, and micronuclei in blood lymphocytes of workers exposed to styrene dur- 
ing the production of reinforced plastics. Environ. Mol. Mutagen. 17, 27--31.

[14] Du, C.L. (1993) Comparison of personal and area sampling strategies in assessing workers' exposure to vinyl chloride monomer. Master thesis, College of Medicine, National Taiwan University, Taipei, pp. 1-42.

[15] Erixon, K. and Ahnstrom, G. (1979) Single-strand breaks in DNA cluring repair of UV-induced damage in normal human and Xeroderma Pigmentosum cells as determined by alkaline DNA unwinding and hydroxylapatite chromatography. Mutat. Res. 59, 257-271.

[16] Walles, S.A.S and Erixon, K. (1984) Single-strand breaks in DNA of various organs of mice induced by methyl methanesulfonate and dimethyl-sulfoxide determined by the alkaline unwinding technique. Carcinogenesis 5 , 319-323.

[17] SAS Institute Inc. (1988) SAS Procedures Guide, release 6.03 ed. Cary N.C.

[18] Cleaver, J.E. (19/8) Methods for studying excision repair of DNA damaged by physical and chemical mutagens. In: B.J. Kilbey (Ed.), Handbook of Mutagenicity Test Procedures, Elsevier Scientific Publishing Company, Amsterdam, pp. 19-37.

[19] Tanaingher, M., Bordone, R., Russo, P., Grilli, S., Santi, L. and Parodi, S. (1987) Major discrepancies between results obtained with two different methods for evaluating DNA damage: alkaline elution and alkaline unwinding. Anticancer Res. 7, 669-680.

[20] Walles, S.A.S and Holmberg, B. (1984) Induction of single-strand breaks in DNA of mice after inhalation of vinyl chloride. Cancer Lett. 25, 13-18.

[21] Engelse, L.D. and De-Brij, R.J. (1980) Persistence and accumulation of (potential) single-strand breaks in liver DNA of rats treated with ethyl methanesulphonate. Cancer Lett. 11, 199-208.

[22] Boerrigter, M.E.T.I and Vijg, J. (1991) Induction and disappearence of DNA single-strand breaks in human B and $T$ lymphocytes after exposure to ethylnitrosourea. Mutat. Res, DNA Repair 255, 49-55.
[23] Velman, G., Lange, C.E., Juhe, S., Stein, G. and Bachner, U. (1975) Clinical manifestations and course of vinyl chloride disease. Ann. N.Y. Acad. Sci. 246, 6-17.

[24] Waxweiler, R.J., Falk, H., McMichael, A., Mallov, J.S., Grivas, A.S. and Stringer, W.T. (1977) A cross-sectional epidemiological survey of vinyl chloride workers. National Institute for Occupational Safety and Health (DHEW publication No. 77-177), Cincinnati.

[25] Lilis, R., Anderson, H., Nicholson, W.J., Daum, S., Fischbein, A.S. and Selikoff, I.J. (1975) Prevalence of disease among vinyl chloride and polyvinyl chloride workers. Ann. N.Y. Acad. Sci. 246, 22.

[26] Wyatt, R.M., Kotchen, J.M., Hochstrasser, D.L., Buchanan, J.W. Jr., Campbell, D.R. and Slaughter, J.C. (1975) An epidemiological study of blood screening tests and illness histories among chemical workers involved in the manufacture of polyvinyl chloride. Ann. N.Y. Acad. Sci. 246, 80-87.

[27] Sugita, M., Masuda, Y. and Tsuchiya, K. (1986) Early detection and signs of hepatoangiosarcoma among vinyl chloride workers. Am. J. Ind. Med. 101, 411-417.

[28] Nosko, M., Zajkov, H., Uzunova, D. and Spasovski, M. (1976) Biochemical disturbance in workers exposed to vinyl chloride. Letopisi na Higienno, Epidemiologicanata Sluzba. 20, 47-50.

[29] Langauer-Lewowicka, H., Kurzbauer, H., Uzunova, D. and Spasovski, M. (1983) Vinyl chloride disease neurological disturbance. Int. Arch. Occup. Environ. Health 52, 151-157.

[30] Rosalki, S.B. (1975) Gamma-glutamyl transpeptidase. Adv. Clin. Chem. 17, 53-107.

[31] Fiala, S., Mohindru, A., Kettering, W.G., Fiala, A.E. and Morris, H.P. (1976) Glutathione and gamma glutamyl transpeptidase in rat liver during chemical carcinogenesis. J. Natl. Cancer. Inst. 57, 591-598.

[32] Hanigen, M.H. and Pitot, H.C. (1985) Gamma-glutamyl transpeptidase - its role in hepatocarcinogenesis. Carcinogenesis $6,165-172$. 